\title{
The Opportunities and Challenges for Running-abroad Schools of Chinese Universities under the One Belt And One Road Initiative
}

\author{
Wang zhihui \\ Yunnan University of Finance and Economics, \\ Kunming, Yunnan, China \\ 328608635@qq.com
}

\author{
Cui yuan \\ Yunnan University of Finance and Economics, \\ Kunming, Yunnan, China \\ 1213293873@qq.com
}

\begin{abstract}
With the continuous expansion of education internationalization, China's higher education has also quickened the pace of "going out" . The One Belt and One Road Initiative has brought unprecedented opportunities to the running-abroad schools of Chinese universities. However, there are still great challenges in the practice of running-abroad schools: the monopoly of developed countries, the imperfections of the relevant policy measures, the lack of curriculum and faculty internalization, all of these have formed hindrance to the running-abroad schools of Chinese universities. This paper discussed the opportunities and challenges faced by running-abroad schools, and put forward some suggestions on the government's policy, such as the establishment of the university alliance, and the improvement of the quality assurance system.
\end{abstract}

Keywords-universities; running-abroad schools; opportunities; challenges

\section{GENERAL SITUATION}

In 2002 , the ministry of education promulgated the interim administrative measures for running-abroad schools (hereinafter referred to the "measures"), which explained the definition of overseas education of running-abroad schools for Chinese universities. It pointed out that Chinese universities run schools abroad, is refers to the institutions of higher learning independently or cooperate with overseas education institutions and other social organizations with legal status held in overseas, in which overseas citizens as the main students. these schools have advanced degrees education, degree education or non-academic higher education.

From the 1970s, China began to explore overseas schools. With the increasing of international communication and cooperation of education, China's "going out" of universities enhances unceasingly. According to the latest statistics from the Ministry of Education, as of March 2016, there were 5 institutions of overseas running schools, and the number of school-running programs has reached 98 , which is distributed in 14 countries and regions.[1] Among them, there are 50 undergraduate programs, accounting for $48.5 \%$ of the total number, and 30 master's degrees and above, accounting for 29.1\%. In February 2017, Peking University HSBC business school and the UK Open University officially signed up to establish the Oxford campus of Peking University HSBC business school. The school district will officially open in 2018. [2]

Generally speaking, overseas education is growing in China, especially after the One Belt And One Road initiative. However, due to it is still in its preliminary stage in china, the concept, scientific research and management mechanism of Chinese universities still have a long distance from the world's advanced level, there are a series of problems to be solved. 


\section{OPPORTUNITIES}

As a new model in China, the overseas education of universities has unprecedented resources in both domestic and foreign environments:

\section{A. The division of international education trade is more and more specified}

According to David Ricardo's theory of comparative advantage, in terms of international trade, each country should concentrate on producing and exporting products with comparative advantages and importing inferior products (that is, two good choice the better one, two bad choice the worse one.), so both sides can save labor force and obtain the benefits of specialization. The international education service also applies to this theory. [3]

Compared with the closed domestic market, the international education market has a broader market demand to China's higher education. For less-developed countries, the quality of local higher education can't meet the needs of the local people due to the lack of resources and high cost. So there is demand for China's higher education resources. Also, even in the developed countries, Chinese universities still have advantages in traditional disciplines such as Mandarin Learning, Traditional Chinese Medicine, Chinese Opera, Martial Arts, Calligraphy and Painting. The introduction of education resources from China could also benefit them.

\section{B. The spread of Chinese culture has become wider and wider.}

In recent years, Chinese traditional culture has been developed and widely spread all over the world. The interest of foreigners in learning Chinese culture is growing, and the international influence of Chinese culture has also been gradually improved.

The blossoming Confucius institute around the world is a great example to show people's huge interest about traditional Chinese culture. At present, China has established 511 Confucius institutes and 1,073 Confucius classrooms in 140 countries and regions. Among them, there are a total of 134 Confucius institutes in 51 countries and regions along the One Belt and One Road, covering nearly 28 EU countries and 16 central and eastern European countries. In addition, Mandarin has been subsumed into the national education system in around 67 countries. [4]

\section{The policy support has been intensified}

Chinese government has always adopted active support policies for running-abroad schools of Chinese universities. The National Medium and Long-term Education Reform and Development Plan Outline (2010-2020) pointed out that "We should support the high level overseas education institutions, strengthen the international communication, cooperation and education services "; In 2013, One Belt And One Road initiative showed that China's opening-up policy has reached a new stage. And in April 2016, the office of the central committee of the communist party of China, and the office of the State Council released about to do a good job of education in the new period, which present new requirements for the opening-up of education and put forward to " Encourage schools and vocational colleges to go out, and social forces to participate in the overseas education.

In July 2016, the Ministry of Education issued the promotion the education action of One Belt And One Road, which provided institutional guarantee and opportunities for overseas education. Since September 2016, the Ministry of Education has gradually signed the memorandum of international cooperation with governments of Gansu, Ningxia, Yunnan and other 14 provinces (areas). The MOE will support these provinces from the following seven aspects: macro guidance, two-way education, foreign-related education, national and regional research, people-to-people and cultural exchanges, capacity building, and platform construction. Besides, The MOE will also lead the signing units to give full play to their location advantages to promote the education action of One Belt And One Road.[5]

Currently, the number of countries on the Belt and Road who have launched the education cooperation with China is still limited. The cooperation with the Czech republic, Hungary, Greece and many other countries has not officially begun, so there is still a lot of potential for cooperation between China and One Belt And One Road countries. 


\section{The discipline competitiveness is getting stronger and} stronger

After years development of science and technology, the ability of research and teaching in Chinese higher education has improved a lot. A group of international faculty have been developed, who can participate in the international competition effectively. According to the ESI database in 1998-2008, China's "985" university's dominant disciplines, such as engineering, chemistry, materials science and other 11 majors which have achieved the first 1 percent of the major in the world, showed that there was a certain professional strength in running a school abroad. For example, Xiamen-Malaysia campus of the university was set up for the chemical engineering which in the top 1\%. [6] At the same time, the development of education has also cultivated a group of international teachers who have mastered the language tools and are familiar with the frontier knowledge and international academic dynamic.

\section{THE CHALLENGES}

\section{A. From the outside environment}

\section{1) The monopoly of developed countries}

For a long time, the international education market has been monopolized by some developed countries. First, in terms of international students market, about $70 \%$ of foreign students, concentrated in the United States, Britain, France, Russia, Japan, Australia and other developed countries.

In addition, in October 2015, there were 230 overseas schools in the world, while the major exporting countries were the United States, Australia, Britain, Germany, France, Spain and other developed countries. Among them, the US dominated the highest output percentage, while Australia had the fastest speed of growth. These countries had more developed higher education system, rich international teaching experiences, so its overseas educational theories and practices have led the world. By contrast, the overseas education of Chinese universities starts a bit late, and the development is relatively lagging behind, so its international competitiveness and brand are not attractive.
2) The conflicts with local customs, culture, policies and regulations

First, running-abroad schools have to adapt to two or even more different customs, culture and regulations. There are many differences in language, culture, politics and religious, which makes people lots of contradictions on the thinking mode, communication methods and values. As a result, overseas education institutes inevitably encounter some conflicts among social norms, cultural etiquette and policies. What is more, some local cultures themselves have strong exclusiveness. For example, a professor taught students in the Horse-angle branch of University of George Mason, he found the difficulty to define the "partner" as "husband" or "wife", which may make certain students unacceptable. [7]

Second, the running-abroad schools are treated as foreign capital enterprises in some countries, which makes these institutions hard to manage, and the quality assurance system of education cannot be implemented in these institutions. Besides, those schools cannot benefit from tax exemption as non-profit organizations, such as business tax, income tax, import tax, etc.[8]

\section{B. From the internal environment.}

\section{1) Imperfect policies}

running-abroad schools involves education sovereignty, foreign regulation, degree certificate, foreign exchange management and many other problems, which requires legislation and identification of its rights and obligations, as well as government policy support. However, at present, there are no specific laws for running-abroad schools, and the existing policies are mainly focused on the "imported" schools rather than "going out" schools.

In addition, the application and procedure for teaching abroad is still very complicated, even if all provinces and cities have formulated the implementation details according to the guidelines on strengthening and improving teaching and research personnel to manage temporary work abroad. This has limited the stability and continuity of the teaching team abroad and brought inconvenience to teaching and administration. 


\section{2) Ineffective quality assurance system.}

China has not set up special quality assurance system and quality evaluation agencies for running-abroad schools yet. The supervision of running-abroad schools can only be carried out by the international cooperation and exchange division of the Ministry of Education, which publishes information on internet regularly and provides official certificate to foreign academic degree. Since these people who are responsible for information updating may have no teaching or administration experience on running-abroad schools, it could lead to serious information asymmetry between the domestic management department and the works in running-abroad schools. [9]

Because of the imperfect quality assurance system, there are countless cases about the interests of educators could not be guaranteed. Such a supervision system has little effect on the quality assurance of running-abroad schools. What's more, it is difficult to balance the needs between the quality and quantity of running-abroad schools for Chinese universities.

\section{3) Inadequate sources of funding}

The current Chinese fiscal policy does not allow public universities to invest in overseas. Therefore, it become difficult for Chinese universities to provide the resources for running-abroad schools. In addition, with the continuous expansion of Chinese universities, lack of funding is a big issue for running-abroad schools. At present, the investment of local social capital is also poor. Therefore, how to guarantee the sustainable development of running-abroad schools, Chinese universities are facing great financial pressure and high financial risks. If Chinese universities cannot provide required funds to support campus construction, teaching equipment, managing personnel, etc., they might face a huge loss in the future.

As for the current running-abroad schools, Laos Suzhou university, which cooperated by a Chinese enterprise with Suzhou university, is expected to foster the talent for Chinese enterprises; Xiamen university's overseas branch is mainly funded by the national development bank; instead of invest lots of money in land, real estate and infrastructure, Bangkok Business school of Yunnan University of Finance and
Economics mainly rely on foreign partner, Rangsit university of Thailand, shared teaching facilities and other equipment.

\section{Challenges faced by Chinese universities}

\section{1) Weak international awareness in the universities}

Most of the Chinese Universities are lack the international consciousness, and could not promote the internationalization of education with self-confidence and long-term perspective. Even in universities with faster internationalization, it is still hard to see English signs on campus and buildings, and the English menus of college canteens are very few. Even the teachers who are responsible of management of foreign students rarely speak fluent English.

The internationalization level of university management needs to be improved. At present, the management system of curriculum, student, staff management and resource in Chinese universities is relatively lag behind, which restricted the speed of internationalization.

\section{2) Incomplete international curriculum system}

There are still many incommensurable aspects in the academic structure of Chinese universities. The teaching mode and training mode of curriculum are urgently needed to be reformed. At the same time, most of the running-abroad schools are mainly specialized in traditional Chinese specialties, such as the university of Suzhou in Laos and the university of Xiamen in Malaysia. Chinese is taken as teaching language in many running-abroad schools, which overlaps with the Confucius institutes. The professional study does not combine academic advantages of Chinese universities and local needs.

\section{3) Insufficient international faculty}

In recent years, the internationalization level of teachers in china are improved, but the number of teachers who can meet the requirements of overseas education is still poor. Teachers with high professional skills have restricted by English, while most young teachers with fluent English are lack of teaching experience and excellent professional knowledge. The language talents of countries along the One Belt And One Road are especially poorer. Generally speaking, there is less than $20 \%$ faculty who can carry out bilingual teaching in 
Chinese universities. It is difficult for these teachers to manage teaching workload effectively between the campus inland and oversea, and they always on "flying" situation, which is harmful for students' study.

\section{SugGestions}

\section{A. Improving relevant policies}

The Chinese government should make clear policies and preferential measures for running-abroad schools. Firstly is to construct a legal framework system for running-abroad schools to integrate education, culture, diplomacy, trade, tourism and other forces in the form of law, and to deal with problems and disputes during the process of running schools oversea.

Secondly, the corresponding policies should be issued as soon as possible, and modify them according to the development of running-abroad schools. Also the appropriate loose fiscal policy and the preferential tax policy should be given for those schools, to actively encourage university "go out". Especially to establish an Overseas-education Fund for Chinese universities, which provide the funding support for running-abroad schools in countries along the "One Belt And One Road". Meanwhile the Chinese government could set up the scholarships for foreign students who are along the One Belt and One Road countries.

\section{B. Expanding the partnerships}

First, Chinese universities should update the management philosophy and seize the opportunities from the One Belt and One Road initiative, to carry out overseas education practice and international exchange programs. At the same time, Chinese universities can enlarge the partnership for running-abroad schools in host country, such as local government, local enterprises and institutions, social groups, and individual citizens. By doing this, multiple management systems could be established to guarantee the sustainable development for running-abroad schools, including diversified investment, various management team and various evaluation systems.

\section{Establishing the alliance universities}

Running-abroad schools should cooperate with each other and establish a university alliance together. For example, universities in Yunnan province can form an alliance with universities in Southeast Asia and South Asia. Through this alliance, student exchange and academic cooperation could be put into practices easily. Students can get credits from any alliance universities, and grant the degree from the university which they got the most credits. At the same time, the research institution and researchers in alliance universities can propose research project together, doing research together, which can promote academic and cultural exchanges between the countries and regions.

\section{Improving the quality assurance system}

Regarding quality assurance, many developed countries take the effective approaches. For example, American model is led by the society, British model focuses on combination of university and society, French model leaded by the government departments while Japanese model is mixed by government and society. [10] In China, the quality assurance for running-abroad schools should be part of university quality assurance system. University should be self-assessed every year according to academic standards and achieve a good internal supervision mechanism. The Ministry of Education should be responsible for setting up standards and frameworks of higher education evaluation.

On the other hand, it is necessary to establish an objective, fair and transparent social evaluation system, and bring the third-party evaluation into the system. The state and regions should support the evaluation by the independent legal personality, and ensure the objectiveness of quality evaluation and academic audit activities.

\section{E. Constructing international faculty and curriculum system}

Chinese university should select good teachers to develop a research team by considering factors such as strong scientific research ability, good professional background and excellent foreign language skills. Also Chinese university should provide foreign language training for faculty on a regular basis, especially on listening, speaking, reading and writing. By doing so, Chinese university can improve international teaching quality and academic communication skills.

At the same time, Chinese university with running-abroad schools, should consider the curriculum model of international standard and market economy environment. Different 
countries needs to adopt different school running modes. For the teaching language, readjusting the proportion of Chinese teaching in running-abroad schools, setting up English teaching system, using the Chinese/English bilingual teaching and other bilingual courses if necessary. In addition, the minority language courses of countries along the One Belt And One Road should be included in the Chinese language curriculum system to meet the urgent needs of language talents.

\section{REFERENCES}

[1] Yan xiao. Analysis of the motivation and countermeasures of overseas running of universities in China $[\mathrm{J}]$. University education management.(in Chinese)

[2] Guangming daily. Peking University HSBC school of business at Oxford campus will be built [EB/OL].http://epaper.gmw.cn/gmrb/html/2017-02/23/nw.D110000gmr b_20170223_3-06.htm? Div = 1(in Chinese)
[3] Zhang jinqing. Research on cross-border higher education [D]. Southwest university. 2012.(in Chinese)

[4] Xiong jianhui. Overseas schooling: "go out" and "walk steadily" [N] Guangming daily.(in Chinese)

[5] Signed by the ministry of education and six provinces (area), city "in" education action international cooperation memorandum. [EB/OL] http://www.moe.edu.cn/jyb_xwfb/gzdt_gzdt/moe_1485/201704/t20170 411_302369.html(in Chinese)

[6] Lin jian, Hu dexin. "One Belt And One Road" national strategy and Chinese engineering education new mission $[\mathrm{J}]$. Higher engineering education research. 2016 (6)(in Chinese)

[7] Du yanfeng. Overseas branch of American colleges and universities: history, status and trend $[\mathrm{J}]$. Foreign education research. 2016. (4)(in Chinese)

[8] Philip G atbach, Jane Wright, beidong, Yang huawei, Chen yibo. Outlook on the internationalization of higher education: motivation and reality $[\mathrm{J}]$. Research on education. 2006 (1).

[9] Zheng hairong. Research on the quality assurance system of China's transnational advanced education [D]. Huazhong university of science and technology,2013.(in Chinese)

[10] Wu jianwei. Comparison and reference of education quality assurance system in foreign countries $[\mathrm{J}]$. Science and education (top 10),2011,(06):1-2(in Chinese). 